\title{
A Gastric Lesion Revealing a Small-Cell Lung Cancer: A Rare Case
}

\author{
Miguel Mascarenhas Saraiva ${ }^{a, b}, c$ Tiago Ribeiro ${ }^{a, b}$ Francisco Moreira $^{d}$ \\ Joanne Lopes ${ }^{d}$ Amadeu Corte Real ${ }^{a, b}$ Guilherme Macedo ${ }^{a, b}, c$ \\ ${ }^{a}$ Department of Gastroenterology, Centro Hospitalar Universitário de São João, Porto, Portugal; bWGO Training \\ Center, Porto, Portugal; ' $F$ aculty of Medicine, University of Porto, Porto, Portugal; ' ${ }^{d}$ Department of Pathology, \\ Centro Hospitalar Universitário de São João, Porto, Portugal
}

Keywords

Small-cell lung cancer · Gastric metastases · Gastrointestinal metastases

\section{Carcinoma Pulmonar de Pequenas Células Revelado por Lesão Gástrica: Um Caso Raro}

\section{Palavras Chave}

Carcinoma pulmonar de pequenas células · Metástases gástricas · Metástases gastrointestinais

Small-cell lung cancer (SCLC) accounts for $15 \%$ of all lung cancer cases. It differs from non-SCLC tumors as it displays a neuroendocrine biosignature [1]. Up to twothirds of SCLC patients present with widespread metastases at diagnosis [1]. Gastric metastases of SCLC are extremely rare and only a small number of reports have been published so far [2].

A 47-year-old male patient presented at the emergency department with persistent nonradiating pain in the right hypochondrium, nausea, anorexia, early satiety, and an 11 -kg weight loss over 1 month. His past medical history was remarkable for heavy smoking, severe chronic obstructive pulmonary disease, and previous intravenous drugs use. Physical examination revealed painful hepatomegaly. Laboratory values demonstrated a microcytic normochromic anemia ( $\mathrm{Hb} 7.2 \mathrm{~g} / \mathrm{dL}$ ), and elevated cholestasis markers (alkaline phosphatase $254 \mathrm{U} / \mathrm{L}$, gammaglutamyl transferase $287 \mathrm{U} / \mathrm{L})$. Abdominal ultrasound showed an enlarged and diffusely nodular liver. Thoracoabdominopelvic CT demonstrated a $2-\mathrm{cm}$ nodule in the inferior lobe of the left lung (Fig. 1a) and signs of diffuse hepatic metastases (Fig. 1b). An upper endoscopy was performed for exploration of his abdominal symptoms and revealed a $1-\mathrm{cm}$ ulcerated nodular lesion in the greater curvature of the gastric body (Fig. 2). Biopsies demonstrated submucosal infiltration of small hyperchromatic cells with scant cytoplasm (Fig. 3a). Immunohistochemistry revealed diffuse immunoreactivity to CAM5.2, synaptophysin, and chromogranin. These findings were compatible with gastric infiltration of neoplastic cells with neuroendocrine differentiation. Liver biopsy was performed and showed similar histology (Fig. 3b, c). karger@karger.com www.karger.com/pjg

Karger $\stackrel{\text { ' }}{=}$

BOPEN ACCESS (c) 2021 Sociedade Portuguesa de Gastrenterologia. Published by S. Karger AG, Basel

This is an Open Access article licensed under the Creative Commons Attribution-NonCommercial-4.0 International License (CC BY-NC) (http://www.karger.com/Services/OpenAccessLicense), applicable to the online version of the article only. Usage and distribution for commercial purposes requires written permission.
Correspondence to:

Miguel Mascarenhas Saraiva, miguelmascarenhassaraiva@gmail.com 

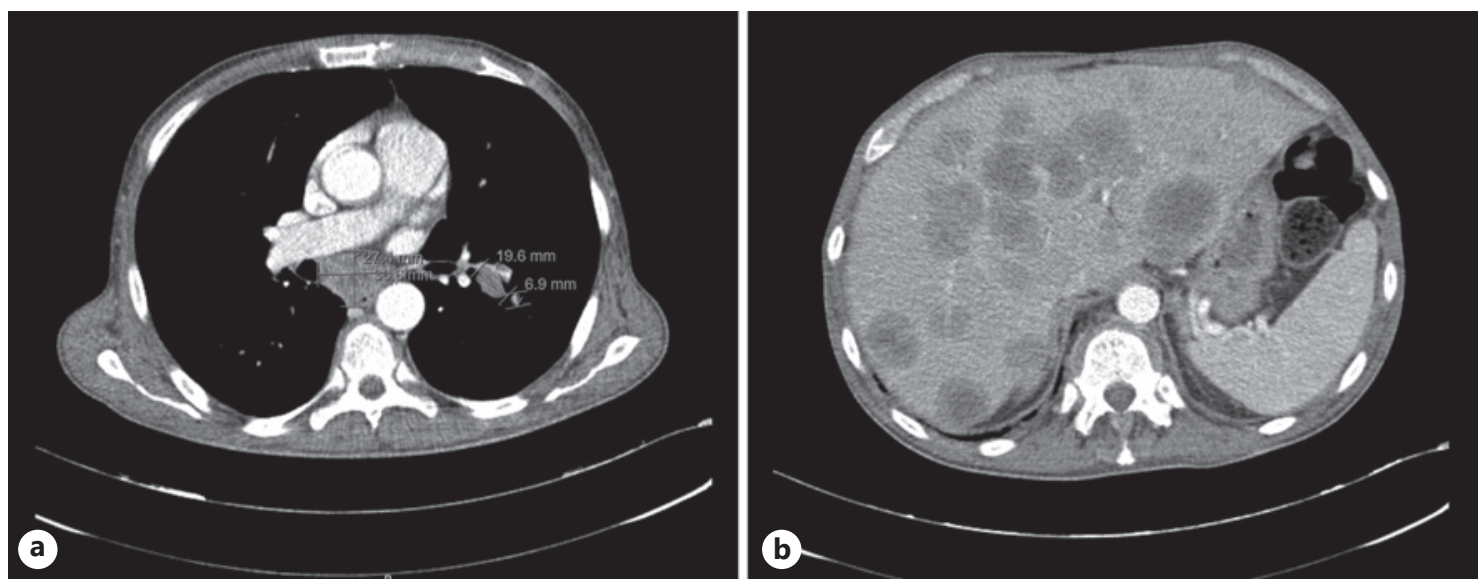

Fig. 1. a CT scan showing a 2-cm nodular lesion in the upper segment of the inferior lobe of the left lung and a $3.7 \times 2.4 \mathrm{~cm}$ infracarinal adenomegaly. $\mathbf{b}$ Hepatomegaly and diffuse hepatic metastases.

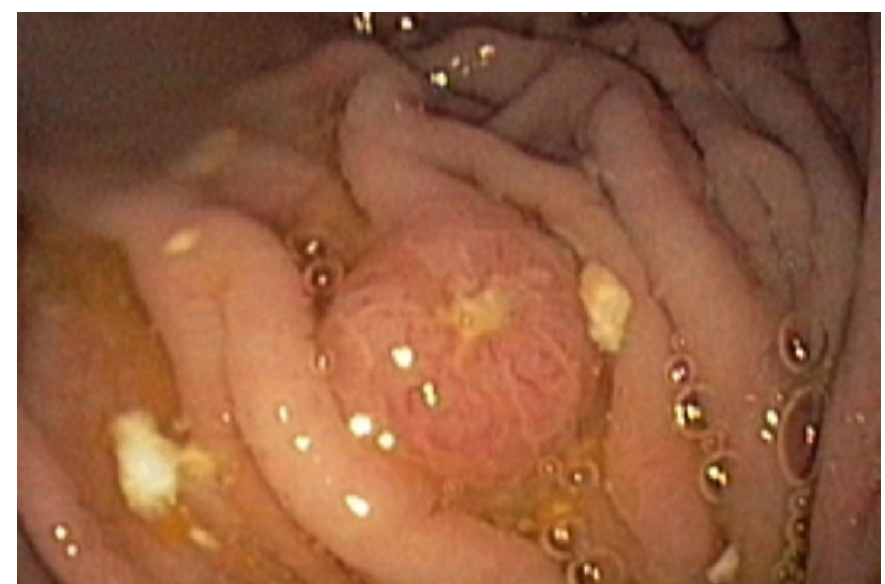

Fig. 2. Nodular lesion with central ulceration in the greater curvature in the body of the stomach.

Bronchoalveolar lavage cytology and bronchial biopsy revealed TTF-1-positive cells with similar expression of neuroendocrine markers, confirming SCLC. A diagnosis of stage IV SCLC was established, and palliative chemotherapy was initiated. The patient's functional status rapidly deteriorated, and he died 3 months after the diagnosis.

SCLC is an aggressive form of lung cancer known for early dissemination, either lymphatic or hematogenous, to the liver, brain, bones, and adrenal glands [3]. Gastric involvement in metastatic SCLC is rare [2]. Diagnosis of gastric SCLC metastases before primary disease is ex- tremely rare [4]. In our case, the occurrence of nonspecific upper gastrointestinal symptoms with red flag signs prompted an endoscopic evaluation. Gastrointestinal metastases become symptomatic when the metastasis has grown substantially as metastatic cells initially infiltrate deeper portions of the bowel wall [4]. Nevertheless, both clinical and endoscopic features are nonspecific, and histopathological analysis is key to a correct diagnosis. In this instance, immunohistochemical identification of neuroendocrine makers such as chromogranin and synaptophysin is critical for identification of cellular lineage [1], and in our case, immunoreactivity to chromogranin and synaptophysin strongly suggested gastric involvement by a neuroendocrine neoplasm, later confirmed as a SCLC metastasis.

The prognosis of SCLC is poor, and a median survival of 4 months after diagnosis of gastric metastasis has been estimated [5]. Treatment of metastatic disease is palliative and first-line regimens include etoposide plus carboplatin or cisplatin [1]. Nevertheless, as described in the reported case, most patients have fast progression, ultimately succumbing to the disease within a few months.

\section{Statement of Ethics}

All rules of the local ethics committee (Comissão de Ética para a Saúde do Centro Hospitalar de São João/Faculdade de Medicina da Universidade do Porto, Portugal) were followed, preserving patient identity and confidentiality. Informed consent was obtained from the patient for publication of his case. 

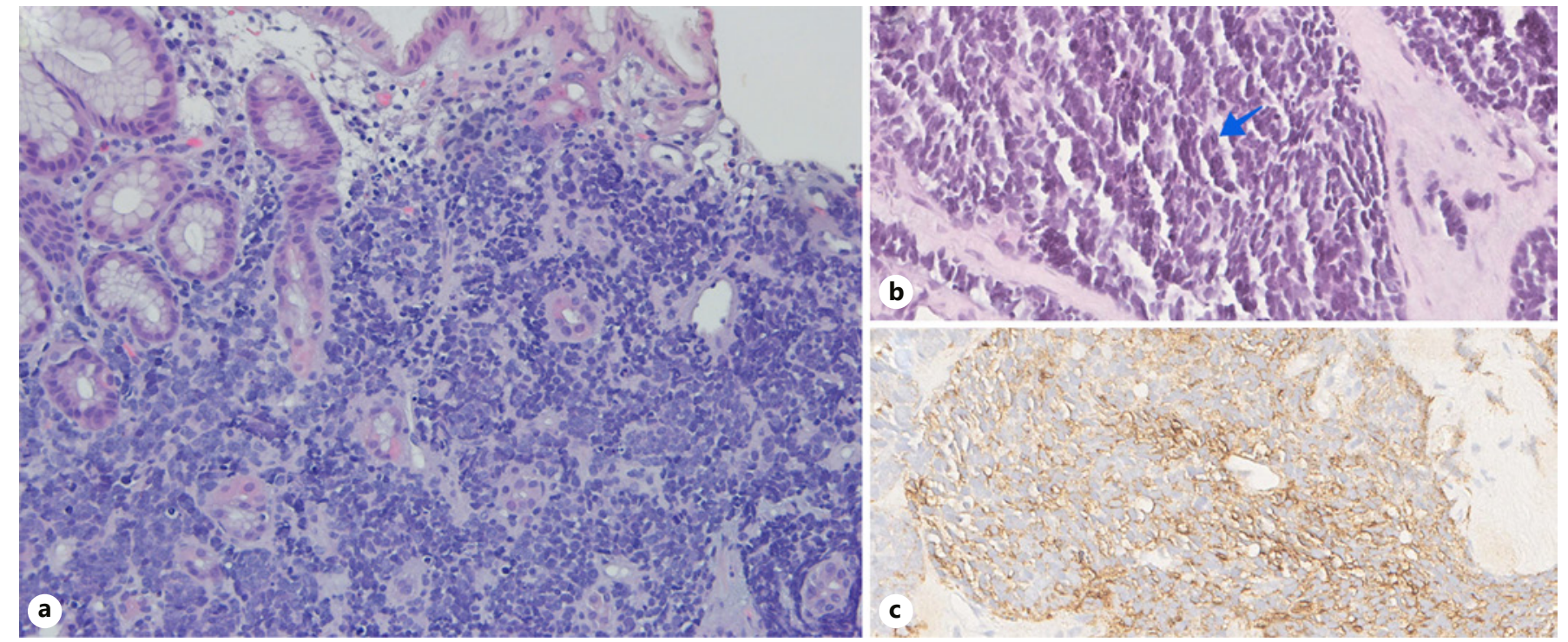

Fig. 3. a Gastric submucosal infiltration of hyperchromatic small neoplastic cells $(H \& E, \times 20)$. b Liver biopsy demonstrating severe infiltration of liver parenchyma by neoplastic cells, with frequent figures of mitosis (arrow) and apoptosis. c Liver biopsy demonstrating immunohistochemical expression of chromogranin neoplastic cells.

\section{Conflict of Interest Statement}

The authors have no conflicts of interest to declare.

Funding Sources

The authors declare that there was no source of funding.
1 van Meerbeeck JP, Fennell DA, De Ruysscher DK. Small-cell lung cancer. Lancet. 2011 Nov;378(9804):1741-55.

2 Gao S, Hu XD, Wang SZ, Liu N, Zhao W, Yu QX, et al. Gastric metastasis from small cell lung cancer: a case report. World J Gastroenterol. 2015 Feb;21(5):1684-8.

3 Gazdar AF, Bunn PA, Minna JD. Small-cell lung cancer: what we know, what we need to know and the path forward. Nat Rev Cancer. 2017 Dec;17(12):725-37.
4 Nitipir C, Ginghina O, Popa L, Andrei F, Tudor N, Radu I, et al. A rare case of advanced lung cancer presenting as a symptomatic gastric tumor. Mol Clin Oncol. 2018 Apr;8(4):595-9.

5 Huang Q, Su X, Bella AE, Luo K, Jin J, Zhang $S$, et al. Clinicopathological features and outcome of gastric metastases from primary lung cancer: A case report and systematic review. Oncol Lett. 2015 Mar;9(3):1373-9. 